\title{
Congenital myelomeningocele - do we have to change our management?
}

\author{
Steffi Mayer, Margit Weisser, Holger Till, Gerd Gräfe, Christian Geyer
}

\begin{abstract}
Background: Eagerly awaiting the results of the Management of Myelomeningocele Study (MOMS) and with an increasing interest in setting up intrauterine myelomeningocele repair (IUMR), the optimal management of patients suffering from congenital myelomeningocele (MMC) has become a matter of debate again. We performed a crosssectional study at our referral-center for MMC to determine the outcome for our expectantly managed patients.

Materials and methods: A computed chart review at our institution revealed 70 patients suffering from MMC. Forty-three patients were eligible for the study and analyzed further. A retrospective analysis was performed only in patients that underwent $M M C$ repair within the first two days of life and were seen at our outpatient clinic between 2008 and 2009 for a regular multidisciplinary follow-up. Data were collected on: gestational age (GA) and weight at birth, age at shunt placement and shunt status after the first year of life, radiological evidence for Arnold-Chiari malformation (ACM) and tethered cord (TC), need for surgery for TC, bladder function, lower leg function and educational level. Data were compared to published results for IUMR and to studies of historical controls.
\end{abstract}

Results: Patients were born with MMC between 1979 and 2009 and are now $13.3 \pm 8.9$ (mean \pm SD) years of age. At birth, mean GA was $37.8 \pm 2.3$ weeks and mean weight was $2921.3 \pm 760.3 \mathrm{~g}$, both significantly higher than in IUMR patients. Shunt placement in our cohort was required in $69.8 \%$ at a mean age of $16.0 \pm 10.7$ days, which was less frequent than for historical controls. Amongst our cohort, radiological observations showed $57.1 \%$ had ACM II and $41.9 \%$ had TC. Only two of our patients underwent a surgical correction for TC. Clean intermittent catheterization was performed in $69.7 \%$ of our patients, $56.4 \%$ were (assisted) walkers and $64.1 \%$ attended regular classes, both comparable to historical controls.

Conclusions: With a close and interdisciplinary management by pediatric surgeons, neurologists and urologists, the long-term outcome of patients suffering from MMC can currently be considered satisfactory. With respect to the known drawbacks of fetal interventions for mother and child, especially preterm delivery, the results of the MOMS trial should be awaited with caution before proceeding with a complex intervention like IUMR.

\section{Background}

Myelomeningocele (MMC) is a mostly isolated congenital disorder of the central nervous system that has a multifactorial etiology. Based on a prevalence of 10-15 per 10,000, more than 4,500 pregnancies are affected in the European Union each year [1]. Its prevalence can be reduced by $50-70 \%$ with maternal $400 \mu \mathrm{g}$ folic acid supplementation before conception and during the first trimester [2,3]. Myelomeningocele is characterized by a protrusion of the meninges and spinal cord through

\footnotetext{
* Correspondence: christian.geyer@medizin.uni-leipzig.de

* Correspondence: christian.geyer@medizin.uni-leipzig.de
Department of Pediatric Surgery, University Hospital Leipzig, Liebigstrasse 20a, 04103 Leipzig, Germany
} 20, 04103 Leipzig, Germany

() Biomed Central

(C) 2010 Mayer et al; licensee BioMed Central Ltd. This is an Open Access article distributed under the terms of the Creative Commons Attribution License (http://creativecommons.org/licenses/by/2.0), which permits unrestricted use, distribution, and reproduction in any medium, provided the original work is properly cited. open vertebral arches which results in varying degrees of paralysis, mental retardation, bowel and bladder dysfunction as well as orthopedic disabilities [4]. After surgical closure of the defect, many patients present with a hydrocephalus that requires the placement of a ventricular shunt to prevent additional cerebral damage, which again is associated with a high rate of complications like dysfunction and infection [5]. Most patients are further affected by an Arnold-Chiari malformation (ACM) due to a downward movement of the hindbrain and obstruction of the normal egress of cerebrospinal fluid (CSF) from the fourth ventricle that increases the 5-year-mortality from $7.9 \%$ to $35 \%$ [6-8]. A high number of patients 
also suffer from spinal cord tethering (TC), which progressively worsens neurological function and frequently requires surgical correction [9]. In 1990, the two-hithypothesis for the pathogenesis of MMC was postulated by Heffez et al: A defective spinal development is followed by an intrauterine injury of the spinal cord due to the exposure to amniotic fluid, meconium and urine, as well as direct trauma and hydrodynamic pressure, thus causing loss of neural tissue due to a progressive cell toxicity over gestation [10-13].

Spina bifida is nowadays diagnosed prenatally in 70$90 \%$ of cases mostly before 20 weeks of gestational age (GA) by routine ultrasound scan $[14,15]$. If the ultrasound scan is positive, amniocentesis is performed to rule out genetic syndromes and to measure alpha-fetoprotein (AFP) levels. Mostly, parents are counseled to opt for expectant management or termination of pregnancy. In the United States, an intrauterine myelomeningocele repair (IUMR) can also be offered. The concept of IUMR is based on the hypothesis that an intrauterine protection of the exposed spinal cord as well as the reduction of continuous intramniotic leakage of CSF might prevent some of its secondary damage $[16,17]$. Since the first intrauterine endoscopic repair in 1994, which was replaced by open surgical repair in 1997, about 400 open fetal interventions for MMC have now been performed worldwide [4]. Preliminary results suggest a reversal of hindbrain herniation, a decrease in shunt-dependent hydrocephalus, an improvement in leg function and an unaltered bladder function after IUMR $[4,18,19]$. However, the technique remains of unproven benefit and the reported findings might be explained by selection bias and changing management indications [20]. Therefore, the Management of Myelomeningocele Study (MOMS), a multicenter, prospective, randomized controlled trial of 200 patients (100 fetal repair, 100 postnatal repair), was set up in 2003 in the US (San Francisco, Nashville and Philadelphia) to primarily investigate death or the need for shunting by the age of one year with and without fetal intervention in MMC http://www.spinabifidamoms.com.

The objective of this study was to decide, whether it is time to offer IUMR at our institution to patients diagnosed prenatally with MMC. Therefore, we performed a retrospective data analysis on expectantly managed patients with MMC that attended our hospital and compared them to results obtained after IUMR at other institutions and to historical controls as collected from the literature.

\section{Methods}

\section{Patient recruitment}

A computed chart review was performed in February 2010 to conduct a descriptive and retrospective study on information obtained from medical reports. Patients were recruited to the study if they suffered from an open spina bifida that was diagnosed pre- or postnatally and underwent surgical repair within the first two days of life to prevent further damage, e.g. by CSF leakage, local infection or scarred shrinking, as generally accepted.

\section{Surgical repair of open spina bifida}

After an ellipsoid incision of the zona cutanea, the zona epithelioserosa was dissected. The dura was mobilized completely and isolated from the fascia thoracolumbalis. The zona epithelioserosa was excised and the neural tube was reconstructed if possible using 10-0 absorbable single sutures. The dural layer was closed in craniocaudal direction using a 6-0 or 7-0 absorbable running suture, exceptionally inserting a dural patch. After the water-tight closure of the dura, the defect was covered by a wing-flap plasty. The fascia thoracolumbalis was dissected and closed before the subcutaneous tissue and skin layer were sutured. A primary stainless skin closure is essential in cases with extremely large defects, for which we preferred longitudinal incisions with mobilization of the skin and temporary skin substitution if necessary. Postoperative monitoring consisted of frequent clinical investigation, measurement of head circumference and cranial ultrasound examination.

\section{Shunt placement}

A ventricular-peritoneal shunt was placed only in the case of symptomatic hydrocephalus, according to similar criteria to that listed in Table 1.

\section{Patient follow-up}

All included patients were regularly seen at our outpatient clinic for a multidisciplinary follow-up, including consultation with a pediatric neurologist, pediatric urologist, pediatric orthopedists and pediatric surgeon. The final follow-up was between 2008 and 2009 in order to assess the patients' current health status.

\section{Data collection}

Data were collected on: GA and weight at birth, neonatal death (defined as death within the first 28 days of life), shunt status at the first year of life and age at shunt placement, radiological presence of $\mathrm{ACM}$ and $\mathrm{TC}$ as assessed postnatally by ultrasound and/or magnetic resonance imaging, the need for surgery for $\mathrm{TC}$, as well as bladder function, lower leg function and educational level. Satisfactory bladder function was defined as use of clean intermittent catheterization (CIC) and satisfactory educational level as regular attendance at kindergarten, school or job. 
Table 1 Criteria for shunt placement

\begin{tabular}{ll}
\hline \multicolumn{1}{c}{ Criteria for Shunt placement (MOMS trial) } \\
\hline At least two of the following: & Or: \\
\hline $\begin{array}{l}\text { An increase in the greatest occipitofrontal circumference adjusted for gestational } \\
\text { age and defined as crossing percentiles }\end{array}$ & Head circumference $>95^{\text {th }}$ percentile for gestational age \\
\hline A bulging fontanelle*, split sutures or sunsetting sign & $\begin{array}{l}\text { Presence of marked syringomyelia (syrinx and expansion of spinal } \\
\text { cord) and ventriculomegaly (undefined) }\end{array}$ \\
\hline $\begin{array}{ll}\text { Increasing hydrocephalus on two consecutive imaging studies determined by an } \\
\text { increase in ratio of biventricular diameter to biparietal diameter }\end{array}$ & $\begin{array}{l}\text { Ventriculomegaly (undefined) and symptoms of Chiari } \\
\text { malformation (stridor, swallowing difficulties, apnea, bradycardia) }\end{array}$ \\
\hline & $\begin{array}{l}\text { Persistent cerebrospinal fluid leakage from the myelomeningocele } \\
\text { wound or bulging at the repair site }\end{array}$ \\
\hline
\end{tabular}

Criteria for shunt placement as defined for the MOMS trial. *Bulging fontanelle: above the bone as assessed when the baby is in an upright position and not crying. ${ }^{\S}$ Defined by O’Hayon et al, 1998 [34]. Table adapted from Tulipan et al, 2004 [35].

\section{Comparison with published data}

We performed computerized bibliographic searches using Pubmed http://www.pubmed.gov and Embase http://www.embase.com databases to identify studies that report on outcome measurements after IUMR ("IUMR group") and for postnatally-managed patients with spina bifida ("historical controls"). If applicable, studies on which the MOMS trial had been based were preferentially included as historical controls. After identification of matching studies, data extraction was performed for outcomes as listed above. If the same outcome was published several times, e.g. mean gestational age at birth, the cohort with the largest number of patients was used for comparison.

\section{Study groups}

The study consisted of three groups: (1) retrospectively assessed data on patients with open spina bifida that underwent MMC closure and follow-up at our institution ("Leipzig group"), (2) published data on patients that underwent IUMR elsewhere ("IUMR group") and (3) published data on patients that were operated postnatally and managed elsewhere, preferentially providing the basis for the MOMS trial ("historical controls") (Table 2).

\section{Statistical analysis}

Data collected from our cohort study ("Leipzig group") were analyzed assessing mean and standard deviation (SD) for continuous data (GA and weight at birth, age at shunt placement) and percentages for dichotomous data (neonatal death, birth before 30 weeks GA, shunt status at the first year of life, radiological presence of ACM II and TC, use of CIC, lower leg function and educational level). The collected results were compared to data published for IUMR and historical controls, respectively. For continuous data two-sided t-tests were applied to compare published means against sample means ("Leipzig group"). In none of the published articles were standard deviations presented. Therefore, similar standard deviations to our studies were used, assuming comparable distributions in similar populations. For nominal data contingency tables were generated from the total numbers of all study groups and tested applying two-sided Fisher's exact test. Regression analysis was further performed to test the correlation between birth year and prenatal diagnosis of our population. All statistical analyses were performed using JMP 7 software (SAS Institute, Cary, NC, USA). Data are given in raw numbers, percentage or mean \pm SD if not indicated differently. Results were considered statistically significant at $p<0.05$.

\section{Results}

\section{Study population}

The chart review revealed 70 patients suffering from spina bifida. Of those, two underwent IUMR elsewhere, five underwent MMC closure beyond the second day of life, 10 had not undergone surgery for MMC at our hospital or the operation date could not be identified and 10 patients were lost from follow-up. Therefore, data from 43 MMC patients that underwent surgical correction for MMC within the first two days of life and had been seen at our outpatient clinic between 06/2008 and $12 / 2009$ were analyzed. All results are summarized in Table 3. The 43 patients were born between 1979 and 2009 and were on average $13.3 \pm 8.9 y$ of age at the time of data analysis. $11.6 \%$ had thoracic, $79.1 \%$ lumbar and $9.3 \%$ sacral lesions (Table 2).

\section{Prenatal diagnosis and birth}

Only $37.2 \%$ of our patients had been diagnosed prenatally with MMC. However, the number of prenatal diagnoses significantly increased over time with a significant correlation between prenatal diagnosis and birth year $(p$ $<0.0001)$. There were no neonatal deaths in our study population compared to $4.5 \%$ after IUMR $(p<0.05)$ [21]. Mean GA at birth in our population $(37.8 \pm 2.3$ weeks) and of historical controls (37.0 weeks) was significantly higher than after IUMR (34.6 weeks; $p<0.001$ ) 
Table 2 Characteristics of patients studied

\begin{tabular}{|c|c|c|c|c|c|c|c|c|c|}
\hline \multirow[t]{2}{*}{ Study Group } & \multirow[t]{2}{*}{ Reference } & \multirow[t]{2}{*}{ Publication Year } & \multirow[t]{2}{*}{ Study Site } & \multirow[t]{2}{*}{ Study Period } & \multirow[t]{2}{*}{$\mathrm{N}$ patients } & \multicolumn{4}{|c|}{ Level of lesion (\%) } \\
\hline & & & & & & thoracic & lumbar & sacral & other \\
\hline $\begin{array}{c}\text { (1) } \\
\text { Leipzig group }\end{array}$ & & & Leipzig, Germany & 1979-2009 & 43 & 11.6 & 79.1 & 9.3 & - \\
\hline \multirow{9}{*}{$\begin{array}{c}\text { (2) } \\
\text { IUMR group }\end{array}$} & Bruner [22] & 1999 & Vanderbilt, USA & 1990-1997 & 29 & \multicolumn{4}{|c|}{ median L4 (S-T12) } \\
\hline & Tulipan [21] & 2003 & CHOP, Vanderbilt, USA & $1983-2000$ & 177 & 4.8 & 80.8 & 14.4 & - \\
\hline & Johnson [24] & 2003 & $\begin{array}{l}\text { CHOP, } \\
\text { USA }\end{array}$ & 1998-2002 & 48 & 5 & 84 & 11 & - \\
\hline & Bruner [25] & 2004 & Vanderbilt, USA & 1997-2003 & 116 & 4.3 & 81.9 & 13.8 & - \\
\hline & Brunner [23] & 2005 & Vanderbilt, USA & $1997-2003$ & 116 & 4.3 & 81.9 & 13.8 & - \\
\hline & $\begin{array}{l}\text { Koh } \\
{[27]}\end{array}$ & 2006 & Boston, USA & $1979-2003$ & 5 & \multicolumn{4}{|c|}{ lumbosacral } \\
\hline & Danzer [26] & 2008 & CHOP, USA & 1998-2003 & 54 & 7.4 & 85.2 & 7.4 & - \\
\hline & Danzer [18] & 2009 & CHOP, USA & 1998-2003 & 54 & 7.4 & 81.5 & 11.1 & \\
\hline & Danzer [29] & 2010 & CHOP, USA & $1998-2003$ & 30 & \multicolumn{4}{|c|}{ median L4 (T12-S1) } \\
\hline \multirow[t]{5}{*}{ (3) Historical controls } & Bruner [22] & 1999 & Vanderbilt, USA & 1990-1997 & 23 & \multicolumn{4}{|c|}{ median L4 (S-T12) } \\
\hline & Bowman [5] & 2001 & Chicago, USA & 1975-1979 & 71 & 35.2 & 42.2 & 21.2 & 1.4 \\
\hline & Tulipan [21] & 2003 & CHOP, Vanderbilt, USA & 1983-2000 & 189 & 18.5 & 60.3 & 21.2 & - \\
\hline & $\begin{array}{l}\text { Koh } \\
{[27]}\end{array}$ & 2006 & Boston, USA & $1979-2003$ & 88 & \multicolumn{4}{|c|}{-} \\
\hline & Aguilera [15] & 2009 & Bristol, UK & 1999-2007 & 74 & 10.8 & 41.9 & 44.6 & 2.7 \\
\hline
\end{tabular}

Summarized characteristics of included studies sorted by study group.

Table 3 Summarized results and statistical comparisons

\begin{tabular}{|c|c|c|c|c|c|c|}
\hline & \multirow[t]{2}{*}{$\begin{array}{c}\text { (1) } \\
\text { Leipzig group }\end{array}$} & \multirow[t]{2}{*}{$\begin{array}{c}\text { (2) } \\
\text { IUMR group }\end{array}$} & \multirow[t]{2}{*}{$\begin{array}{c}\text { (3) } \\
\text { Historical controls }\end{array}$} & \multicolumn{3}{|c|}{$\begin{array}{c}\text { Statistical comparison } \\
\text { ( } p \text {-value) }\end{array}$} \\
\hline & & & & (2) vs (3) & (1) vs (2) & (1) vs (3) \\
\hline Neonatal death (\%) & 0 & $4.5[21]$ & NA & - & $<0.05$ & - \\
\hline \multirow[t]{2}{*}{ GA at birth (wk) } & $37.8 \pm 2.3$ & $34.6[21]$ & $37.0[22]$ & - & $<0.0001$ & ns \\
\hline & & $33.2[22]$ & $37.0[22]$ & $<0.001[22]$ & - & - \\
\hline GA < 30th wk (\%) & 0 & $11.8[23]$ & NA & - & $<0.05$ & - \\
\hline \multirow[t]{2}{*}{ Birth weight (g) } & $2921.3 \pm 760.3$ & 2512 [24] & $3075[22]$ & - & $<0.01$ & ns \\
\hline & & $2171[22]$ & $3075[22]$ & $<0.001[22]$ & - & - \\
\hline $\begin{array}{l}\text { Shunt placement } \\
\leq 1 \text { y }(\%)\end{array}$ & 69.8 & $54.3[25]$ & $85.7[21]$ & $<0.0001$ & ns & $<0.05$ \\
\hline \multirow{2}{*}{$\begin{array}{l}\text { Age at shunt } \\
\text { placement }(d)\end{array}$} & $16.0 \pm 10.7$ & $21.2[24]$ & - & - & $<0.05$ & - \\
\hline & $12.5^{\S}$ & $85.5[22]^{\$}$ & $5[28]^{\$}$ & $<0.01[22]$ & - & - \\
\hline $\begin{array}{l}\text { Incidence } \\
\text { ACM II (\%) }\end{array}$ & 57.1 & $100^{\S}$ & 75.7 [15] & - & - & ns \\
\hline Surgery TC (\%) & 11.1 & $29.6[26]$ & $32.4[5]$ & ns & $<0.01$ & $<0.001$ \\
\hline (Assisted) Walkers (\%) & $56.4^{f}$ & $92.6[18]^{\#}$ & $59.2[5]^{9}$ & $<0.0001$ & $<0.0001$ & ns \\
\hline Wheelchair users (\%) & $41.0^{£}$ & $7.4[18]^{\#}$ & $40.8[5]^{\pi}$ & $<0.0001$ & $<0.0001$ & ns \\
\hline Regular education (\%) & 64.1 & NA & $63.4[5]$ & - & - & ns \\
\hline$\overline{C I C}(\%)$ & 69.7 & NA & $84.5[5]$ & - & - & ns \\
\hline
\end{tabular}

Summarized results of our data collection compared to published results for historical controls and IUMR applying the two-sided t-test or Fisher's exact test at $p$ $<0.05$. Data are presented in mean $( \pm$ SD) or median and percentages. GA: gestational age, ACM: Arnold-Chiari malformation, TC: tethered cord, CIC: clean intermittent catheterization. NA: not applicable, ns: not significant. ${ }^{5}$ median; ${ }^{5} \mathrm{ACM}$ is one of the inclusion criteria for IUMR; ${ }^{⿷}$ mean age $13.3 \pm 8.9$ years, ${ }^{\#}$ mean age $67.0 \pm 18.2$ months, "mean age 21.7 years. 
without a significant difference between our population and historical controls $[21,22]$. None of our patients but $11.8 \%$ of the children after IUMR were born before 30 weeks of gestation $(p<0.05)$ [23]. Mean weight at birth in our group was $2921.3 \pm 760.3 \mathrm{~g}$, which was significantly higher than after IUMR $(2512 \mathrm{~g} ; p<0.01)$ and not significantly different from historical controls (3075 g) $[22,24]$.

\section{Shunt status}

Among historical controls, median $85.7 \%$ of the patients required shunt placement within the first year of life, which was significantly different from median 54.3\% after IUMR $(p<0.0001)$ and from $69.8 \%$ in our study population $(p<0.05)[21,25]$. On the contrary, there was no significant difference for the need of shunting within the first year of life between IUMR and our population. However, the average age at shunt placement was significantly higher after IUMR (mean 21.2 days) than in our study population (mean $16.0 \pm 10.7$ days; $p<0.05$ ). Likewise, median age at shunt placement was significantly higher after IUMR as compared to historical controls (85 vs. 5 days; $p<0.01$ ) [22,24].

\section{Arnold-Chiari malformation and tethered cord}

ACM II was radiologically diagnosed in $57.1 \%$ of our patients, one patient presented with ACM I. The incidence of ACM II was not different from historical controls (75.7\%) [15]. Among our patients 18 (41.9\%) presented with tethered cord and only two $(11.1 \%)$ of them had to undergo surgery for TC so far, which is significantly less than after IUMR $(29.6 \% ; p<0.01)$ and less than for historical controls $(32.4 \% ; p<0.001)$, whereas the latter two did not differ significantly $[5,26]$.

\section{Quality of life}

In our population $56.4 \%$ and in historical controls $59.2 \%$ were assisted walkers that ambulate most of the time, both of which are significantly different from $92.6 \%$ of the patients after IUMR $(p<0.0001)[5,18]$. Likewise, $40.8 \%$ of historical controls and $41.0 \%$ of our study population were reliant on a wheelchair, which is significantly more than after IUMR $(7.4 \% ; p<0.0001)$. CIC was regularly performed in $69.7 \%$ of our population and similarly in $84.5 \%$ of historical controls [5]. Conversely, all patients after IUMR but only $38 \%$ of historical controls showed detrusor overactivity, suggesting that IUMR is associated with a higher incidence of complete denervation of the external urethral sphincter and detrusor overactivity [27]. A similar proportion of patients in all three groups attended regular education, suggesting adequate intellectual development $(64.1 \%, 76.7 \%$ and $63.4 \%$ for Leipzig, IUMR and historical groups, respectively) $[5,18]$. There was no significant difference between shunted and non-shunted patients for the attendance of regular education in our population $(80 \%$ vs. $58.6 \%)$. After IUMR, $67 \%$ of the patients had normal cognitive language and personal-social skills, $20 \%$ had mild and 13\% significant delays at the age of two years, $23 \%$ were at risk for (significant) learning disabilities, with the majority $(85.7 \%)$ shunted $[28,29]$.

\section{Discussion}

Myelomeningocele is a congenital anomaly that affects about 1,500 infants per year in the US, of which recently more than $90 \%$ survive the first year of life and about $75 \%$ will reach adulthood [5]. Even though MMC is a non-lethal birth defect, it is the associated life-long morbidity that motivates clinicians all over the world to examine the value of fetal therapy. The aim of IUMR is to improve postnatal morbidity and in particular neurological outcome by reduction of secondary injury to the spinal cord [30]. This should be achieved by coverage of the spinal defect to stop CSF leakage and to prevent secondary damage, which in turn might allow normal brain development. The initial fetoscopical approach failed to show convincing benefit due to a high rate of perinatal deaths, which could be ruled out when standard neurosurgical closure of the defect was performed prenatally via a hysterotomy [30]. Since then, in about 400 cases of IUMR a reversal of hindbrain herniation, a decrease in shunt-dependent hydrocephalus and an improved leg function as compared to historical controls have been suggested [4]. Those results will be confirmed or rejected in the randomized controlled MOMS trial that was initiated in 2003 in three major centers for fetal surgery in the US to evaluate potential benefits after prenatal versus postnatal MMC closure. While keenly awaiting the results of the trial, we performed a retrospective analysis on patients from our referral center for MMC and reviewed the literature to compare the outcomes of MMC patients treated at our institution with published data from IUMR and historical controls.

Comparable to historical controls, mean gestational age at birth in our patients was 37.8 weeks and no prenatal deaths were recorded. In contrast, after IUMR, mean gestational age at birth was 34.6 weeks with $11.8 \%$ of the infants born before 30 weeks of gestation, both significantly different from historical controls and our findings [21-23]. Perinatal mortality after IUMR was $5.9 \%$ [24]. As Bruner et al stated in 2005, virtually all fetuses that underwent IUMR deliver preterm and more than $10 \%$ even before 30 weeks, thus risking major morbidity [23]. That prompts the question if the postulated benefits of IUMR on hindbrain herniation, shunt-dependent hydrocephalus and leg function justify the associated risks for mother and child when IUMR in turn may cause major morbidity and neonatal death due to 
preterm delivery in a condition that is usually non-lethal [24]. Lethal complications due to chorioamnionitis, placental abruption and preterm premature rupture of the membranes have been reported in particular for endoscopic IUMR, diminishing a fetoscopic approach for MMC in the late 1990s [30]. To what extent surgical risks and preterm delivery due to open IUMR contributes to major morbidity and neonatal death cannot be estimated from the available data but might be answered by the MOMS trial.

The second main outcome of the MOMS trial, besides neonatal death, is the need for shunting. As compared to historical controls, the rate of shunting within the first year of life was significantly lower in our cohort and after IUMR, whereas the latter two did not differ significantly. This observation is backed up by the findings of others that reported shunt rates of $78 \%$ ( $\mathrm{n}=$ $203)$ and $43.3 \%(n=293)$, respectively, for postnatallymanaged patients [31,32]. One reason for the discrepancy in shunt rates might be the inconsistency in clinical criteria for shunting, suggesting that the criteria characterized for the MOMS trial should become generally accepted (Table 1).

Another important finding of our study was the discrepancy in the rate of assisted walkers and wheelchair users between our population/historical controls and IUMR, for which $92.6 \%$ (assisted) walkers and only $7.4 \%$ wheelchair users have been reported [18]. At first glance this highly significant difference encourages the efforts of IUMR. However, the mean age of the study population was 21.7 years for historical controls, 13.3 years for our population and only 67.0 months after IUMR. Our results strengthen the finding that mobility decreases from early childhood to the early teen years [33]. Bowman et al showed that the percentage of patients ambulating the majority of time decreased from $76 \%$ at $0-5$ years to $46 \%$ at $20-25$ years, with a flattening beyond 10 years [5]. Assuming a similar progression for children that underwent IUMR, less than 50\% might continue to be assisted walkers in their teens.

We are aware of the drawbacks of the conducted study, which might be affected by the inhomogeneity of study designs, study populations, outcome measurements and treatment modality between centers as well as by changes over time. Thus, our retrospectively-collected data might be compared to results assessed in varying populations, suggesting the comparison of 'apples and oranges'. However, we performed a comprehensive review of the literature to identify the best matching study groups for IUMR and historical controls in the outcomes of our interest. Even though studies varied in their study periods and sites, study populations consisted of patients with similar levels of lesions, a factor known to importantly influence the clinical course in MMC. Therefore, we assume that our cohort, as well as the study population of included studies reflects representative cross-sections of the 'true' MMC population.

\section{Conclusions}

Considering the limitations of the presented study and the data available today, a clear benefit of IUMR has not yet been proven. The implementation of a close interdisciplinary management following postnatal MMC closure results in satisfactory long-term outcomes of patients suffering from this defect. With regards to the wellknown challenges of fetal interventions for both, mother and child, in particular preterm delivery, we actually do not consider the implementation of IUMR at our institution as imperative and the results of the MOMS trial should be awaited before initiating a complex intervention like IUMR.

\section{List of abbreviations used}

ACM: Arnold-Chiari malformation; CIC: clean intermittent catheterization; GA: gestational age; IUMR: intrauterine myelomeningocele repair; MMC: myelomeningocele; MOMS: Management of Myelomeningocele Study; TC: tethered cord

\section{Authors' contributions}

CG and SM conceived of the study. MW, GG and CG carried out the outpatient clinic and data collection. SM carried out data retrieval, performed the statistical analysis and drafted the manuscript. CG and HT helped to draft the manuscript. All authors read and approved the final manuscript.

\section{Competing interests}

The authors declare that they have no competing interests.

\section{Received: 20 July 2010 Accepted: 14 October 2010}

Published: 14 October 2010

\section{References}

1. Busby A, Abramsky L, Dolk H, Armstrong B, Eurocat Folic Acid Working Group: Preventing neural tube defects in Europe: population based study. BMJ 2005, 330:574-575.

2. CDC: Recommendations for the use of folic acid to reduce the number of cases of spina bifida and other neural tube defects. Morb Mortal Wkly Rep 1992, 41:1-6.

3. MRC, Vitamin Study Research Group: Prevention of neural tube defects: results of the Medical Research Council Vitamin Study. Lancet 1991, 338:131-137.

4. Adzick NS: Fetal myelomeningocele: natural history, pathophysiology, and in-utero intervention. Semin Fetal Neonatal Med 2010, 15:9-14.

5. Bowman RM, McLone DG, Grant JA, Tomita T, Ito JA: Spina bifida outcome: a 25-year prospective. Pediatr Neurosurg 2001, 34:114-120.

6. Bol KA, Collins JS, Kirby RS, National Birth Defects Prevention Network: Survival of infants with neural tube defects in the presence of folic acid fortification. Pediatrics 2006, 117:803-813.

7. Wong LY, Paulozzi LJ: Survival of infants with spina bifida: a population study, 1979-94. Paediatr Perinat Epidemiol 2001, 15:374-378.

8. Walsh DS, Adzick NS, Sutton LN, Johnson MP: The Rationale for in utero repair of myelomeningocele. Fetal Diagn Ther 2001, 16:312-322.

9. Adzick NS, Walsh DS: Myelomeningocele: prenatal diagnosis, pathophysiology and management. Semin Pediatr Surg 2003, 12:168-174. 
10. Heffez DS, Aryanpur J, Hutchins GM, Freeman JM: The paralysis associated with myelomeningocele: clinical and experimental data implicating a preventable spinal cord injury. Neurosurgery 1990, 26:987-992.

11. Meuli M, Meuli-Simmen C, Hutchins GM, Seller MJ, Harrison MR, Adzick NS: The spinal cord lesion in human fetuses with myelomeningocele: implications for fetal surgery. J Pediatr Surg 1997, 32:448-452.

12. Drewek MJ, Bruner JP, Whetsell WO, Tulipan N: Quantitative analysis of the toxicity of human amniotic fluid to cultured rat spinal cord. Pediatr Neurosurg 1997, 27:190-193.

13. Correia-Pinto J, Reis JL, Hutchins GM, Baptista MJ, Estevão-Costa J, Flake AW, Leite-Moreira AF: In utero meconium exposure increases spinal cord necrosis in a rat model of myelomeningocele. J Pediatr Surg 2002, 37:488-492.

14. Garne E, Loane M, Dolk H, De Vigan C, Scarano G, Tucker D, Stoll C, Gener B, Pierini A, Nelen V, Rösch C, Gillerot Y, Feijoo M, Tincheva R, Queisser-Luft A, Addor MC, Mosquera C, Gatt M, Barisic I: Prenatal diagnosis of severe structural congenital malformations in Europe. Ultrasound Obstet Gynecol 2005, 25:6-11.

15. Aguilera $S$, Soothill $P$, Denbow M, Pople I: Prognosis of spina bifida in the era of prenatal diagnosis and termination of pregnancy. Fetal Diagn Ther 2009, 26:68-74.

16. Tulipan N, Bruner JP: Myelomeningocele repair in utero: a report of three cases. Pediatr Neurosurg 1998, 28:177-180.

17. Adzick NS, Sutton LN, Crombleholme TM, Flake AW: Successful fetal surgery for spina bifida. Lancet 1998, 352:1675-1676.

18. Danzer E, Gerdes M, Bebbington MW, Sutton L, Melchionni J, Adzick NS, Wilson RD, Johnson MP: Lower extremity neuromotor function and shortterm ambulatory potential following in utero myelomeningocele surgery. Fetal Diagn Ther 2009, 25:47-53.

19. Holzbeierlein J, Pope JC IV, Adams MC, Bruner J, Tulipan N, Brock JW: The urodynamic profile of myelodysplasia in childhood with spinal closure during gestation. J Urol 2000, 164:1336-1339.

20. Sutton L: Fetal surgery for neural tube defects. Best Pract Res Clin Obstet Gynaecol 2008, 22:175-188.

21. Tulipan N, Sutton L, Bruner JP, Cohen BM, Johnson M, Adzick NS: The effect of intrauterine myelomeningocele repair on the incidence of shunt-dependent hydrocephalus. Pediatr Neurosurg 2003, 38:27-33.

22. Bruner JP, Tulipan N, Paschall RL, Boehm FH, Walsh WF, Silva SR, HernanzSchulman M, Lowe LH, Reed GW: Fetal surgery for myelomeningocele and the incidence of shunt-dependent hydrocephalus. JAMA 1999, 282:1819-1825.

23. Bruner JP, Tulipan N: Intrauterine repair of spina bifida. Clin Obstet Gynecol 2005, 48:942-955.

24. Johnson MP, Sutton L, Rintoul N, Crombleholme TM, Flake AW, Howell LJ, Hedrick HL, Wilson RD, Adzick NS: Fetal myelomeningocele repair: shortterm clinical outcomes. Am J Obstet Gynecol 2003, 189:482-487.

25. Bruner JP, Tulipan N, Reed G, Davis GH, Bennett K, Luker KS, Dabrowiak ME: Intrauterine repair of spina bifida: preoperative predictors of shuntdependent hydrocephalus. Am J Obstet Gynecol 2004, 190:1305-1312.

26. Danzer E, Adzick NS, Rintoul N, Zarnow D, Schwartz E, Melchionni J, Ernst L, Flake AW, Sutton L, Johnson MP: Intradural inclusion cysts following in utero closure of myelomeningocele: clinical implications and follow-up findings. J Neurosurg Pediatrics 2008, 2:406-413.

27. Koh CJ, DeFilippo RE, Borer JG, Khoshbin S, Bauer SB: Bladder and external urethral sphincter function after prenatal closure of myelomeningocele. J Urol 2006, 176:2232-2236.

28. Johnson MP, Gerdes M, Rintoul N, Pasquariello P, Melchionni J, Sutton L, Adzick NS: Maternal-fetal surgery for myelomeningocele: neurodevelopmental outcomes at 2 years of age. Am J Obstet Gynecol 2006, 194:1145-1150, discussion 1150-1152.

29. Danzer E, Gerdes M, Bebbington MW, Zarnow DM, Adzick NS, Johnson MP: Preschool neurodevelopmental outcome of children following fetal myelomeningocele closure. AJOG 2010, 202:450-459.

30. Bruner JP, Tulipan NB, Richards WO, Walsh WF, Boehm FH, Vrabcak EK: In utero repair of myelomeningocele: a comparison of endoscopy and hysterotomy. Fetal Diagn Ther 2000, 15:83-88.

31. Talamonti G, D'Aliberti G, Collice M: Myelomeningocele: long-term neurosurgical treatment and follow-up in 202 patients. J Neurosurg 2007, 107:368-386.
32. Radmanesh F, Nejat F, El Khashab M, Ghodsi S, Ardebili H: Shunt complications in children with myelomeningocele: effect of timing of shunt placement. Clinical article. J Neurosurg Pediatr 2009, 3:516-520.

33. McLone DG: Continuing concepts in the management of spina bifida. Pediatr Neurosurg 1992, 18:254-256.

34. O'Hayon BB, Drake JM, Ossip MG, Tuli S, Clarke M: Frontal and occipital horn ratio: $A$ linear estimate of ventricular size for multiple imaging modalities in pediatric hydrocephalus. Pediatr Neurosurg 1998, 29:245-249.

35. Tulipan N: Intrauterine closure of myelomeningocele: an update. Neurosurg Focus 2004, 16:E2.

doi:10.1186/1743-8454-7-17

Cite this article as: Mayer et al:: Congenital myelomeningocele - do we have to change our management?. Cerebrospinal Fluid Research 2010 7:17

\section{Submit your next manuscript to BioMed Central and take full advantage of:}

- Convenient online submission

- Thorough peer review

- No space constraints or color figure charges

- Immediate publication on acceptance

- Inclusion in PubMed, CAS, Scopus and Google Scholar

- Research which is freely available for redistribution

Submit your manuscript at www.biomedcentral.com/submit
C Biomed Central 